\title{
Chemometric Analysis of ESIMS and NMR Data from Piper Species
}

\author{
Lydia F. Yamaguchi, ${ }^{a}$ Giovana C. Freitas, ${ }^{a}$ Nidia C. Yoshida,${ }^{a}$ Renata A. Silva, ${ }^{a}$ Anderson M. Gaia,${ }^{a}$ \\ Adalberto M. Silva, ${ }^{a}$ Marcus T. Scotti, ${ }^{b}$ Vicente de P. Emerenciano, ${ }^{a}$ Elsie F. Guimarães, ${ }^{c}$ \\ Eny I. S. Floh, ${ }^{d}$ Carlos A. Colombo, ${ }^{e}$ Walter J. Siqueira ${ }^{e}$ and Massuo J. Kato*,a \\ ${ }^{a}$ Departamento de Química Fundamental, Instituto de Química, Universidade de São Paulo, \\ 05508-000 São Paulo-SP, Brazil \\ ${ }^{b}$ Centro de Ciências Aplicadas e Educação (Campus IV), Universidade Federal da Paraíba, \\ 58297-000 Rio Tinto-PB, Brazil \\ 'Instituto de Pesquisas Jardim Botânico do Rio de Janeiro, Rua Jardim Botânico, 1008, \\ 22460-070 Rio de Janeiro-RJ, Brazil \\ ${ }^{d}$ Departamento de Botânica, Instituto de Biociências, Rua do Matão, 277, \\ 05422-970 São Paulo-SP, Brazil \\ ${ }^{e}$ Centro de Genética Biologia Molecular e Fitoquímica, Instituto Agronômico de Campinas, \\ Av. Barão de Itapura, 1481, 13001-970 Campinas-SP, Brazil
}

O perfil metabólito baseado na aplicação de análises multivariadas (análise de componentes principais, PCA) dos dados de espectrometria de massas com ionização electrospray (ESIMS) no modo positivo e de ressonância magnética nuclear (RMN) do ${ }^{1} \mathrm{H}$ de extratos brutos de espécies de Piper destacou algumas espécies caracterizadas pela produção de lignanas ( $P$. solmsianum, $P$. truncatum e P. cernuum), neolignanas ( $P$. regnellii) e cromenos ( $P$. gaudichaudianum). Análises específicas em conjunto de espécies caracterizadas morfologicamente por apresentarem inflorescências pêndulas e globosas ( $P$. caldense, $P$. carniconnectivum, $P$. bowiei e $P$. permucronatum) ou em espécies que produzem amidas indicaram o potencial mais significativo para tais análises como critério para estudos fitoquímicos posteriores. Análises intraespecíficas de plântulas das espécies $P$. solmsianum, $P$. regnellii e $P$. gaudichaudianum indicaram uma composição química nas folhas baseada na presença dos fenilpropanóides dilapiol e apiol, diferentemente do que produzem as plantas adultas. No caso das espécies que produzem amidas, a composição apresentou-se relativamente constante independentemente do estágio de desenvolvimento.

The metabolomic profiling based on the application of multivariate analysis (principal component analysis, PCA) of positive mode electrospray ionization mass spectrometric (ESIMS) and ${ }^{1} \mathrm{H}$ nuclear magnetic resonance (NMR) data of crude extracts highlighted some species characterized by lignans ( $P$. solmsianum, $P$. truncatum and $P$. cernuum), neolignans ( $P$. regnellii) and chromenes $(P$. gaudichaudianum). A specific analysis focusing on species having pendant and globular inflorescences (P. caldense, $P$. carniconnectivum, $P$. bowiei and $P$. permucronatum) or amides-producing species indicated higher potential of the methodology in determining similarities and establishing priorities for further phytochemical investigation. Such intraspecific analysis applied to analyzed seedling leaves of the $P$. solmsianum, $P$. regnellii and $P$. gaudichaudianum species revealed the production of dillapiole and apiole instead of lignans, neolignans or prenylated benzoic acid, produced by the adult leaves, respectively. In case of amides-producing species, a similar profile was observed regardless the developmental stage.

Keywords: Piperaceae, principal component analysis, secondary metabolites, fingerprinting

*e-mail: majokato@iq.usp.br 


\section{Introduction}

The knowledge on secondary chemistry of tropical plant species is limited to approximately $5-10 \%$ of the total species described so far. In fact, this limited study indicates the potential for finding novel lead compounds from tropical biodiversity. Despite the availability of high throughput technology platforms to detect bioactive compounds, the process of cataloguing their composition possesses a significant challenge since it still involves largely the isolation and spectroscopic characterization of individual components. Additionally, the determination of a more complete profile in terms of secondary compounds in a given species is not a simple task since it should also be considered all organs, tissues, different developmental stages and populational analysis of species as potential sources of material to be further analyses. To make the process even more complex, further variability of chemical composition can be caused by stress and/or responses resulting from interaction of plants with associated flora and fauna or other types of stimuli. ${ }^{1}$

The metabolome represents the collection of all metabolites in a given level of organization of an organism, which are the products of cellular processes. The metabolomic analysis has become an increasingly important approach due to its potential applications in drug discovery, functional genomics of plants, food science and human nutrition..$^{2-5}$ In addition, the metabolomic analysis at specific times throughout the development of tissues or organs can provide information on biosynthetic sites and dynamics of the metabolites. Currently, various experimental techniques have been routinely applied to metabolomic analysis including gas chromatography-mass spectroscopy (GCMS), ${ }^{1} \mathrm{H}$ nuclear magnetic resonance (NMR), electrospray ionization mass spectrometry (ESIMS), high performance liquid chromatography-mass spectrometry (HPLCMS), center for environmental mass spectrometry (CEMS) or a combination of them. ${ }^{6-12}$ Since the generated data are very large and complex for interpreting, the principal component analysis (PCA) has been frequently used to analyze all types of matrices because the method is capable of extracting relevant information from large collection of samples having large number of variables which together make the manual analysis virtually impossible..$^{13-15}$

Piperaceae species are very common in the tropics with ca. 3000 species among which Peperomia and Piper are the most abundant. Some of them, such as P. nigrum L. (black pepper) and P. methysticum G. Forst (kava-kava) are well-known for their commercial and sociocultural uses. Peperomia species are well-known as ornamental plants, although several of them are mentioned as medicinal. In terms of ecological importance, Piper species have been considered as model due to the richness of species and diversity of interactions with herbivores. ${ }^{16-21}$ In general, Piperaceae species can be easily propagated and the availability of data on taxonomy, molecular phylogeny, ecology and chemical composition provides the basis for multidisciplinary studies.

Most of the phytochemical investigation has been addressed to determine major bioactive secondary metabolites and thus, Piperaceae species have shown to produce amides, pyrones, chromenes and lignoids. ${ }^{22-28}$ Several Piper species are pioneer, and can be found in forest borders and for such reason they are also under risk of depletion by anthropic activities. Thus, the preservation of germplasm is highly desirable but the development of methodology for analyzing and recording the chemical profile of large number of species is also urgently required. So far, the methodology based on GCMS was applied to analyze Piperaceae species for determining the composition of essential oils ${ }^{29-33}$ and amides. ${ }^{34}$ Besides, HPLC and LCMS were applied for isolating and identifying unsaturated amides..$^{35}$ Thus, the primary aim of this work was to explore the application of ESIMS and NMR combined with PCA to analyze crude extracts of Piper species in order to determine chemical variability among species and also to establish priorities for phytochemical investigations.

\section{Results and Discussion}

\section{Secondary metabolite profiling}

The Piper species for the chemical profiling studies have been collected in the past five years in different sites (Table 1). The analysis of constituents in crude extracts was initially performed on ${ }^{1} \mathrm{H}$ NMR (300 MHz) (Figure S1 from Supplementary Information, SI) and ESIMS data (Schemes 1-3). The analysis of a set of samples by ${ }^{1} \mathrm{H}$ NMR considered the region between $\delta 9.0-3.0$, excluding the intense peaks resulting from the ubiquitous presence of fatty material. Initial score plot (PC1 vs. PC2) of ${ }^{1} \mathrm{H}$ NMR data revealed a remarkable differentiation of Piper solmsianum C. DC. individuals (K-487A-F) as outliers of the remaining species, which clustered in the center of the score plot (Figure 1). The corresponding loading plot (Figure 2) revealed that the major contribution for such leverage was due to the high intensity of methoxyl signals $\left(\delta 3.88\right.$ and 3.84) resulting from the lignan grandisin (5). ${ }^{36}$ In this particular case, the ${ }^{1} \mathrm{H}$ NMR spectrum indicated that the crude extracts of K-487D contained almost exclusively 
Table 1. Piper species analyzed by ${ }^{1} \mathrm{H}$ NMR, ESIMS and PCA

\begin{tabular}{|c|c|c|c|c|}
\hline Species & Voucher & Abbreviations & Site & $\begin{array}{l}\text { Compound } \\
\text { (references) }\end{array}$ \\
\hline P. aduncum $\mathrm{L}$. & $\begin{array}{l}\text { K-876 } \\
\text { K-057 }\end{array}$ & $\begin{array}{c}\text { Padun } \\
\text { PadunB }\end{array}$ & $\begin{array}{c}\text { Guaraqueçaba-PR } \\
\text { São Paulo-SP }\end{array}$ & $11 \mathrm{a}, 11 \mathrm{~b},{ }^{37} 19^{38}$ \\
\hline P. amalago $\mathrm{L}$. & $\begin{array}{l}\text { K-826 } \\
\text { K-110 }\end{array}$ & $\begin{array}{c}\text { Pamal } \\
\text { PamalB }\end{array}$ & $\begin{array}{l}\text { Encantado-ES } \\
\text { São Paulo-SP }\end{array}$ & $23 \mathrm{~b},{ }^{34} 28^{39}$ \\
\hline P. arboreum Aubl. & $\begin{array}{l}\text { K-680 } \\
\text { K-683 } \\
\text { K-688 } \\
\text { K-053 } \\
\end{array}$ & $\begin{array}{l}\text { ParbA } \\
\text { ParbB } \\
\text { ParbC } \\
\text { ParbD } \\
\end{array}$ & $\begin{array}{c}\text { Mateiros-TO } \\
\text { Ponte Alta do Tocantins-TO } \\
\text { Barreiras-BA } \\
\text { São Paulo-SP } \\
\end{array}$ & $26^{40}$ \\
\hline P. bowiei Yunck. & K-364 & Pbow & São Paulo-SP & 18 \\
\hline P. caldense C. DC. & $\begin{array}{l}\text { K-480 } \\
\text { K-842 } \\
\text { K-484 } \\
\text { K-869 } \\
\text { K-951 } \\
\end{array}$ & $\begin{array}{l}\text { Pcald } \\
\text { PcaldA } \\
\text { PcaldB } \\
\text { PcaldC } \\
\text { PcaldD } \\
\end{array}$ & $\begin{array}{c}\text { Ubatuba-SP } \\
\text { Ubatuba-SP } \\
\text { Ubatuba-SP } \\
\text { Guaraqueçaba-PR } \\
\text { Ubatuba-SP } \\
\end{array}$ & $15^{41}$ \\
\hline P. carniconnectivum C. DC. & $\begin{array}{l}\text { K-963 } \\
\text { K-976 } \\
\text { K-991 } \\
\text { K-978 } \\
\end{array}$ & $\begin{array}{l}\text { PcarnA } \\
\text { PcarnB } \\
\text { PcarnC } \\
\text { PcarnD } \\
\end{array}$ & $\begin{array}{l}\text { Carajás-PA } \\
\text { Carajás-PA } \\
\text { Carajás-PA } \\
\text { Carajás-PA }\end{array}$ & $\mathrm{Nd}$ \\
\hline P. сегnиит Vell. & $\begin{array}{c}\mathrm{K}-137 \\
\mathrm{~K}-1004 \\
\end{array}$ & $\begin{array}{l}\text { PcernA } \\
\text { PcernB }\end{array}$ & $\begin{array}{c}\text { Carajás-PA } \\
\text { São Paulo-SP } \\
\end{array}$ & $7 a^{42}$ \\
\hline P. corcovadensis (Miq.) C .DC. & K-569 & Pcorc & São Paulo-SP & $25^{43}$ \\
\hline P. crassinervium Kunth & K-091 & Pcrass & São Paulo-SP & $14,{ }^{44} 16,{ }^{45} 17 \mathrm{a}, 17 \mathrm{~b}^{42}$ \\
\hline P. cubataonum C.DC. & $\begin{array}{l}\text { K-198 } \\
\text { K-327 } \\
\text { K-469 }\end{array}$ & $\begin{array}{l}\text { PcubA } \\
\text { PcubB } \\
\text { PcubC }\end{array}$ & $\begin{array}{c}\text { Itatiaia-RJ } \\
\text { Cunha-SP } \\
\text { Ilha Grande-RJ }\end{array}$ & $\mathrm{Nd}$ \\
\hline P. dilatatum Rich. & $\begin{array}{l}\text { K-465 } \\
\text { K-490 } \\
\text { K-499 } \\
\text { K-998 } \\
\end{array}$ & $\begin{array}{l}\text { PdilA } \\
\text { PdilB } \\
\text { PdilC } \\
\text { PdilD } \\
\end{array}$ & $\begin{array}{c}\text { São Paulo-SP } \\
\text { Ubatuba-SP } \\
\text { São Paulo-SP } \\
\text { Parauapebas-PA } \\
\end{array}$ & $11 d^{46}$ \\
\hline P. diospyrifolium Kunth. & $\mathrm{K}-431$ & Pdios & São Paulo-SP & $\mathrm{Nd}$ \\
\hline P. fuligineum Kunth. & K-676 & Pful & Mateiros-TO & $\mathrm{Nd}$ \\
\hline P. gaudichaudianum Kunth. & $\begin{array}{l}\text { K-031 } \\
\text { K-489 } \\
\text { K-953 } \\
\end{array}$ & $\begin{array}{l}\text { PgauA } \\
\text { PgauB } \\
\text { Pgau } \\
\end{array}$ & $\begin{array}{c}\text { São Paulo-SP } \\
\text { Ubatuba-SP } \\
\text { Pedra Menina-ES } \\
\end{array}$ & $12^{47}$ \\
\hline P. hispidum $\mathrm{Sw}$. & $\begin{array}{l}\text { K-672 } \\
\text { K-675 } \\
\text { K-742 } \\
\end{array}$ & $\begin{array}{l}\text { PhispA } \\
\text { PhispB } \\
\text { PhispC } \\
\end{array}$ & $\begin{array}{c}\text { Alto Paraíso de Goiás-GO } \\
\text { Pindorama de Tocantins-TO } \\
\text { Ananindeua-PA } \\
\end{array}$ & $22,27^{48}$ \\
\hline P. hostmannianum C. DC. & K-983 & Phost & Carajás-PA & $13^{49}$ \\
\hline P. lhotzlkyanum (Miq.) Kunth. & $\begin{array}{c}\mathrm{K}-890 \\
\mathrm{~K}-1078 \\
\end{array}$ & $\begin{array}{l}\text { PlhotzA } \\
\text { PlhotzB }\end{array}$ & $\begin{array}{l}\text { Monte Verde-MG } \\
\text { Monte Verde-MG }\end{array}$ & $11 \mathrm{c}, 17 \mathrm{a}^{50}$ \\
\hline P. magnificum Trel. & K-491 & Pmag & Manaus-AM & $\mathrm{Nd}$ \\
\hline P. malacophylum C. DC. & $\mathrm{K}-448$ & Pmall & Intervales-SP & $30 \mathrm{a}, 30 \mathrm{~b}^{51}$ \\
\hline P. marginatum Jacq. & $\begin{array}{l}\text { K-759 } \\
\text { K-969 } \\
\text { K-223 } \\
\end{array}$ & $\begin{array}{l}\text { PmargA } \\
\text { PmargB } \\
\text { PmargC }\end{array}$ & $\begin{array}{c}\text { Melgaço-PA } \\
\text { Carajás-PA } \\
\text { São Paulo-SP } \\
\end{array}$ & $1 \mathrm{a}, 1 \mathrm{~b}, 2,17 \mathrm{a}, 17 \mathrm{~b}^{52}$ \\
\hline P. miquelianum C. DC. & $\mathrm{K}-862$ & Pmiq & Guaraqueçaba-PR & $\mathrm{Nd}$ \\
\hline P. peltatum $\mathrm{L}$. & K-599 & Ppelt & Santa Teresa-ES & $\mathrm{Nd}$ \\
\hline P. permucronatum Yunck. & $\begin{array}{c}\text { K-325 } \\
\text { K-397 } \\
\text { K-850 } \\
\text { K-310 } \\
\text { K-1022 } \\
\end{array}$ & $\begin{array}{l}\text { PpermA } \\
\text { PpermB } \\
\text { PpermC } \\
\text { PpermD } \\
\text { PpermE } \\
\end{array}$ & $\begin{array}{c}\text { Cunha-SP } \\
\text { Ubatuba-SP } \\
\text { Ubatuba-SP } \\
\text { São Paulo-SP } \\
\text { Cubatão-SP } \\
\end{array}$ & $17 \mathrm{a}$ \\
\hline P. pseudopothifolium C. DC. & $\mathrm{K}-112$ & Ppseudo & São Paulo-SP & $\mathrm{Nd}$ \\
\hline P. regnellii (Miq.) C. DC. & $\mathrm{K}-242$ & PregA & São Paulo-SP & $4 \mathrm{a}, 6,7^{53}$ \\
\hline P. reticulatum $\mathrm{L}$. & K-970 & Pret & Carajás-PA & $8 c,{ }^{54} 23 a,{ }^{55} 23 b,{ }^{34} 29^{56}$ \\
\hline P. richardiaefolium Kunth. & $\begin{array}{l}\text { K-253 } \\
\text { K-839 } \\
\text { K-290 } \\
\end{array}$ & $\begin{array}{l}\text { PrichardA } \\
\text { PrichardB } \\
\text { PrichardC }\end{array}$ & $\begin{array}{l}\text { São Paulo-SP } \\
\text { São Paulo-SP } \\
\text { São Paulo-SP } \\
\end{array}$ & 9a-9c, 10a, 20a \\
\hline P. scutifolium Yunck. & $\begin{array}{l}\text { K-574 } \\
\text { K-923 }\end{array}$ & $\begin{array}{l}\text { PscutA } \\
\text { PscutB }\end{array}$ & $\begin{array}{l}\text { Cubatão-SP } \\
\text { Ubatuba-SP }\end{array}$ & $25^{43}$ \\
\hline
\end{tabular}


Table 1. continuation

\begin{tabular}{|c|c|c|c|c|}
\hline Species & Voucher & Abbreviations & Site & $\begin{array}{l}\text { Compound } \\
\text { (references) }\end{array}$ \\
\hline \multirow[t]{6}{*}{ P. solmsianum $\mathrm{C}$. DC. } & K-604 & PsolmA & Santa Maria de Jetibá-ES & $3,4 a, 4 b, 5^{36}$ \\
\hline & & PsolmB & & \\
\hline & & PsolmC & & \\
\hline & $\mathrm{K}-487$ & PsolmD & São Paulo-SP & \\
\hline & & PsolmE & & \\
\hline & & PsolmF & & \\
\hline \multirow[t]{3}{*}{ P. truncatum Vell. } & $\mathrm{K}-211$ & Ptrun & São Paulo-SP & $8 a,{ }^{52}$ \\
\hline & K-597 & PtrunA & Santa Maria de Jetibá-ES & \\
\hline & $\mathrm{K}-616$ & PtrunB & Santa Teresa-ES & \\
\hline P. tuberculatum Jacq. & K-169 & Ptub & São Paulo-SP & $20 \mathrm{a},{ }^{43} 21,24,{ }^{40}$ \\
\hline
\end{tabular}

Nd: not determined.<smiles>[R]c1cc2c(cc1C(=O)CC)OCO2</smiles>

1a $R=H$

$1 \mathrm{~b} \mathrm{R}=\mathrm{OMe}$<smiles>CCC(O)c1ccc2c(c1)OCO2</smiles>

2<smiles>C/C=C/c1cc(OC)c(OC)c(OC)c1</smiles><smiles>[R][R4]OC</smiles>

4a $\mathrm{R}^{1}=\mathrm{OMe} ; \mathrm{R}^{2}=\mathrm{H}$ 4b $\mathrm{R}^{1}=\mathrm{H} ; \mathrm{R}^{2}=\mathrm{OMe}$<smiles>COc1cc(C2OC(c3cc(OC)c(OC)c(OC)c3)C(C)C2C)cc(OC)c1OC</smiles><smiles>C/C=C/c1ccc2c(c1)C(C)C(c1ccc(O)cc1)O2</smiles><smiles>C/C=C/c1cc(OC)c2oc(-c3ccc4c(c3)OCO4)c(C)c2c1</smiles><smiles>[R]c1ccc(C2OCC3C(c4ccc([R])c([R])c4)OCC23)cc1[R]</smiles><smiles>[R]c1ccc(CC2COC(=O)C2Cc2ccc([R])c([R])c2)cc1[R]</smiles>

$$
\begin{aligned}
& \text { 8a } R^{1}=R^{2}=R^{3}=R^{4}=O M e \\
& \text { 8b } R^{1}+R^{2}=R^{3}+R^{4}=O \mathrm{OH}_{2} \mathrm{O} \\
& \text { 8c } R^{1}=R^{2}=O M e ; R^{3}+R^{4}=\mathrm{OCH}_{2} \mathrm{O}
\end{aligned}
$$<smiles>[R20]Oc1ccc(CC2COC(O)C2Cc2ccc3c(c2)OCO3)cc1[R20]</smiles>

$$
\begin{aligned}
& \text { 10a } R^{1}+R^{2}=C_{2} \\
& \text { 10b } R^{1}=M e ; R^{2}=H
\end{aligned}
$$

Scheme 1.

grandisin (Figure 1). Other specimens of $P$. solmsianum (K-487A-C, E-F) differing from K-487D appeared together P. truncatum Vell., P. hispidum Sw., P. regnellii (Miq.) C. DC. and P. cernuum Vell. The inspection of the ${ }^{1} \mathrm{H}$ NMR spectra of the extracts from $P$. solmsianum specimens (K-487A-C, E-F) revealed the presence of the phenylpropanoid isoelemicin (3) in addition to grandisin, as confirmed by HPLC-ESIMS analysis. Such chemical variability within the $P$. solmsianum species suggested more detailed investigation of the ${ }^{1} \mathrm{H}$ NMR data. Thus, samples of $P$. regnellii (with exception of sample D) were characterized by the presence dihydrobenzofuran neolignans conocarpan (6) and eupomatenoid (7)..$^{53}$ The set of species including $P$. richardiaefolium Kunth, P. truncatum, P. pseudopothifolium C. DC. and P. cernuum belonging to the clade Macrostachys ${ }^{57}$ is characterized by the production of furofuran lignans, such as eudesmin $(\mathbf{8 a})$, sesamin $(\mathbf{8 b})$, dibenzylbutyrolactone hinokinin (9a), kusunokinin (9b), arctigenin (9c) and dibenzylbutyrolactols derivatives $(\mathbf{1 0 a}, \mathbf{1 0 b})^{42}$ (Table 1). Nevertheless, only few accesses were differentiated out of the major clustering, in the PCA score plot, indicating a possible chemical variability in this clade and that some similarities of signals corresponding to aromatic hydrogens and methoxyl groups may have caused grouping with $P$. solmsianum, $P$. hispidum and $P$. regnellii. Next, the attempt to get higher resolution among species by removal of the outlier group of species was hampered by the lack of clustering. In order to examine the application of an alternative technique, the ESIMS obtained by direct infusion was evaluated to analyze 
<smiles>[R]Cc1cc(C(=O)OC)cc2c1OC([R])(C)C=C2</smiles>

11a $\mathrm{R}^{1}=\mathrm{OH} ; \mathrm{R}^{2}=\mathrm{Me}$<smiles>CC(C)=CCCC1(C)C=Cc2cc(C(=O)O)cc(CC=C(C)C)c2O1</smiles><smiles>COC(=O)c1ccc(O)c(CC(O)C(C)(C)O)c1</smiles><smiles>CC(C)=CCCC(C)(O)C(=O)c1cc(C(=O)O)ccc1O</smiles>

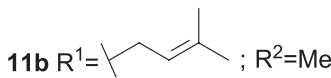<smiles>[Y10]=C[R]=C(C)CC=C(C)C</smiles>

11d $R^{1}=H ; R^{2}=M e$<smiles>C/C=C/CC/C(=C\CC/C(C)=C/CC/C(C)=C/Cc1cc(C(=O)O)cc(O)c1O)C(=O)O</smiles><smiles>O=C1CC(c2ccc(O)cc2)Oc2cc(O)cc(O)c21</smiles>

16<smiles>[R20]c1ccc(C2CC(=O)c3c(O)cc([R20])cc3O2)cc1</smiles>

17a $\mathrm{R}^{1}=\mathrm{Me} ; \mathrm{R}^{2}=\mathrm{H}$ 17b $R^{1}=H ; R^{2}=M e$<smiles>COc1c(O)cc(O)c2c1OC(c1ccccc1)CC2=O</smiles>

18

Scheme 2.
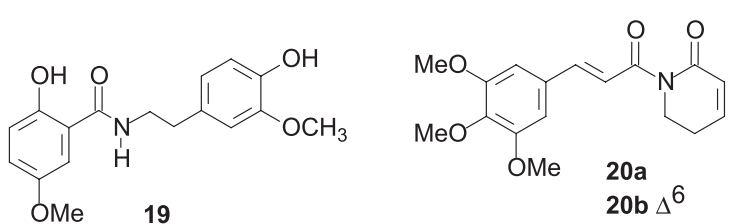<smiles>COc1cc2c(cc1/C=C/C(=O)N1CCCCC1)OCO2</smiles>

21<smiles>COc1ccc(C/C=C/C=C/C(=O)NCC(C)C)cc1</smiles>
24 23a 23b $\Delta^{4}$<smiles>CCCCCc1ccc2c(c1)OCO2</smiles>
27<smiles>O=C(/C=C/C=C/CCc1ccc2c(c1)OCO2)N1CCCC1</smiles>

28<smiles>N#CC(OC(=O)c1ccccc1)c1ccccc1</smiles>

29<smiles>COc1cc2c(cc1/C=C/C(=O)N1CCCC1)OCO2</smiles>

Scheme 3.

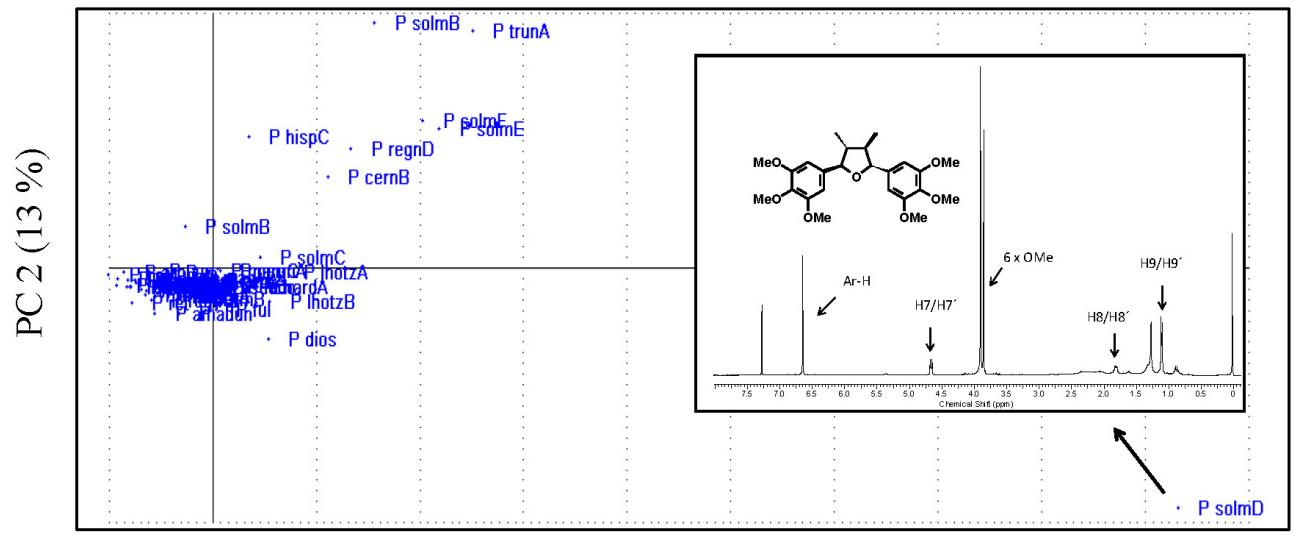

PC $1(61 \%)$

Figure 1. Score plot (PC1 vs. PC2) of ${ }^{1} \mathrm{H}$ NMR (3010 MHz) data of crude extracts from Piper species with $74 \%$ of the variance within the dataset. The insert refers to the ${ }^{1} \mathrm{H}$ NMR spectrum of the crude extracts of $P$. solmsianum (K-487D) showing the predominance of signals of the lignan grandisin. 


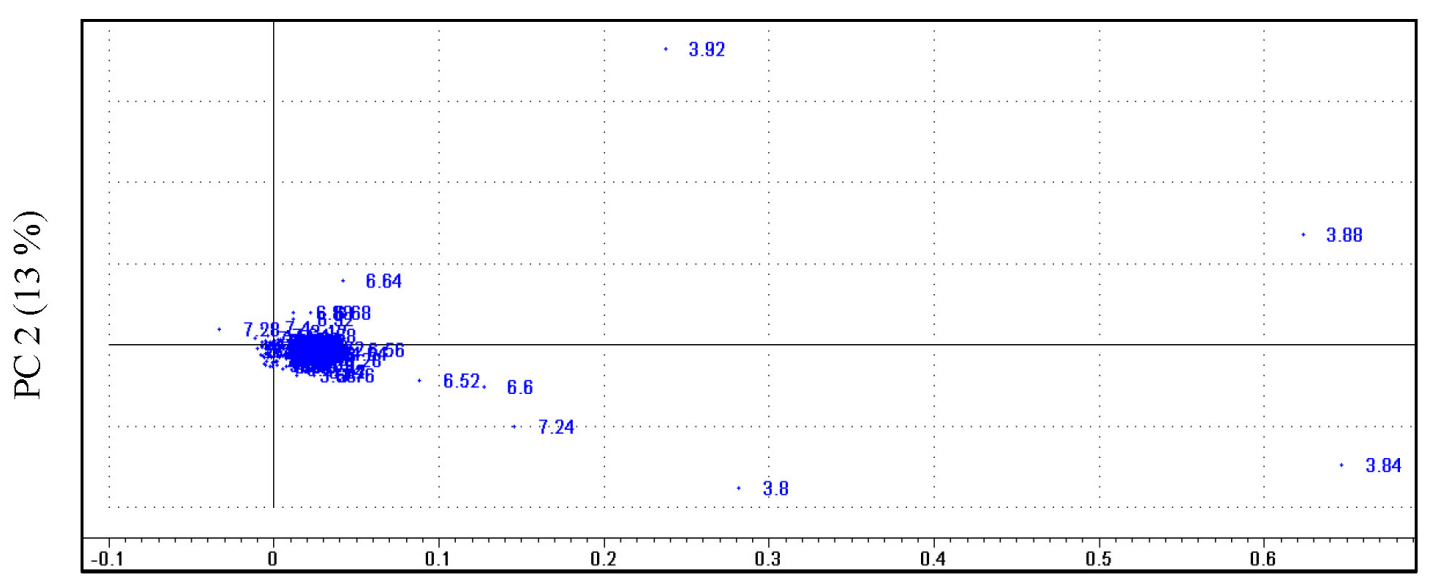

PC $1(61 \%)$

Figure 2. Loading plot of ${ }^{1} \mathrm{H}$ NMR $(300 \mathrm{MHz})(\delta 8.0-3.0 \mathrm{ppm})$ of crude extracts from Piper species with $74 \%$ of the variance within the data set. The signals far from the center are due to methoxyl groups.

the extracts from Piper species. All extracts were analyzed under the positive mode (see Experimental section). The score plot of ESIMS data provided similar results to the case of using ${ }^{1} \mathrm{H}$ NMR with differentiation of the same outlier group of species. Preliminary conclusions regarding the application of metabolome analysis to a large and heterogeneous collection of Piper extracts indicated that this kind of unsupervised analysis should be restricted to a limited group of species or to analyze members of a given population.

Thus, based on the initial conclusion above mentioned, the methodology was next applied to investigate a specific set of samples of different organs belonging to the clade Peltrobryon (Table 2), such as P. caldense C. DC. collected in different sites (K-484, K-842 and K-951), and also P. bowiei Yunck. (K-364), P. permucronatum Yunck. (K-310 and K-1022) and P. carniconnectivum C. DC. (K-963, K-976, K-978, K-991 and K-989). All these four Piper species have in common relatively large and pendant fruits. Previous chemical studies carried out on roots and leaves of $P$. caldense revealed an aristolactam ${ }^{58}$ and a prenylated benzoic acid (caldensinic acid $\mathbf{1 5})^{41}$ as major compounds, while for $P$. carniconnectivum, the composition of essential oil, a flavonoid and cyclopentenediones were reported. ${ }^{59-61}$ The $P$. permucronatum species had only its essential oil described, ${ }^{62}$ while $P$. bowiei has no previous phytochemical study. The analysis carried out using ESIMS of crude extracts combined with PCA provided better differentiation among three groups of samples than using the ${ }^{1} \mathrm{H}$ NMR data (Figures 3 and S2 from SI). The $P$. bowiei (K-364), P. permucronatum (K-310 and K-1022) species were closely related but distinguished from $P$. caldense (K484, K-842 and K-951), while P. carniconnectivum showed some chemical variability in spite of few samples analyzed.
Table 2. Piper species belonging to the clade Peltrobryon analyzed by PCA

\begin{tabular}{lccc}
\hline Species & organ & Voucher & Site \\
\hline P. bowiei & leaves & K-364 L & São Paulo-SP \\
P. caldense & leaves & K-484 L & Ubatuba-SP \\
P. caldense & leaves & K-842 L & Ubatuba-SP \\
P. caldense & twigs & K-842 T & Ubatuba-SP \\
P. caldense & fruits & K-842 Fr & Ubatuba-SP \\
P. caldense & seeds & K-842 S & Ubatuba-SP \\
P. caldense & leaves & K-951 L & Ubatuba-SP \\
P. caldense & twigs & K-951 T & Santa Tereza-ES \\
P. caldense & fruits & K-951 Fr & Santa Tereza-ES \\
P. caldense & seeds & K-951 S & Santa Tereza-ES \\
P. caldense & stems & K-951St & Santa Tereza-ES \\
P. caldense & roots & K-951 R & Santa Tereza-ES \\
P. permucronatum & leaves & K-310 L & São Paulo-SP \\
P. permucronatum & leaves & K-1022 L & Cubatão-SP \\
P. permucronatum & twigs & K-1022 T & Cubatão-SP \\
P. carniconnectivum & leaves & K-963 L & Carajás-PA \\
P. carniconnectivum & leaves & K-976 L & Carajás-PA \\
P. carniconnectivum & leaves & K-978 L & Carajás-PA \\
P. carniconnectivum & leaves & K-991 L & Carajás-PA \\
P. carniconnectivum & leaves & K-989 L & Carajás-PA \\
\hline & & & \\
& & & \\
\hline
\end{tabular}

In order to characterize these groups of species, the major compounds were isolated and spectroscopically analyzed (see Experimental section). Thus, the two samples of $P$. caldense (K-842 and K-951) were consistently characterized by the caldensinic acid (15) as previously isolated. Samples from P. carniconnectivum (K-991, K-976, K-978 and K-989) were more distant from the first species due to the compound 


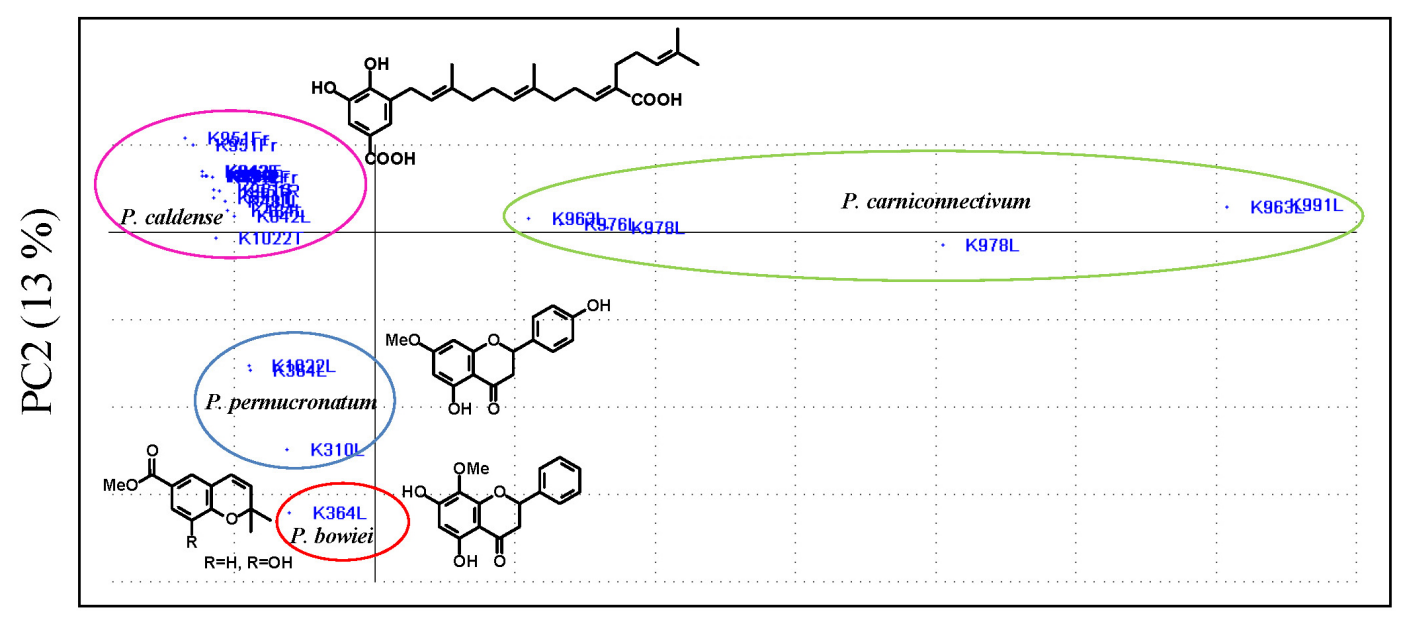

PC1 (57\%)

Figure 3. Score plot (PC1 vs. PC2) of ESIMS data of crude extracts from selected Piper species with $70 \%$ of the variance within the dataset.

with a quasi-molecular ion at $[\mathrm{M}+\mathrm{H}]^{+}$of 335 (Figure $\mathrm{S} 2$ ), whose structure is under investigation. Finally, the $P$. bowiei (K-364) and P. permucronatum (K-310 and K-1022) species were characterized by the isomeric flavanones having the same quasi-molecular ion at $[\mathrm{M}+\mathrm{H}]^{+} 287$ and corresponded to dihydrowogonin (18) and sakuranetin (17a), respectively (see Experimental section). The analysis of this set of samples by HPLC-UV displayed distinct chromatographic profiles (data not shown), and the visualization of some patterns using PCA analysis should be expected if retention time is used as variable. However, the two species (P. bowiei and P. permucronatum) closely clustered in the score plot of ESIMS data because of the same molecular ion that is provided by the isomeric flavanones.

Next, the application of PCA analysis based on the ESIMS data was evaluated to examine the extracts from amide-accumulating species including P. tuberculatum L.,
P. peltatum L., P. scutifolium Yunck., P. reticulatum L. and P. amalago $\mathrm{L}$. The phylogenetic relationship is supported by floral morphology or ITS (internal transcribed spacer) sequences ${ }^{57,63}$ and partially by previous phytochemical data. To date, the chemistry of P. amalago is represented by several amides including nigrinodine $(\mathbf{2 8})^{34,39}$ and terpenes, ${ }^{64-66}$ while for a specimen of $P$. reticulatum from Trinidad and Tobago, two aliphatic pyrones and amide dihydrowisanidine (23a) were described. ${ }^{57}$ The score plot (PC1 vs. PC2) of ESIMS data characterizes the species according to the presence of piplartine (20a) (P. tuberculatum $)^{48}$ and piperovatine (25) (P. scutifolium and P. peltatum $)^{43}$ (Figures 4 and S3 from SI). The P. miquelianum C.DC. species has no report on chemical composition and studies for its detailed composition, being still required. The sample of $P$. amalago contains the amide nigrinodine (28), as previously described. ${ }^{61}$ The pyrones previously described

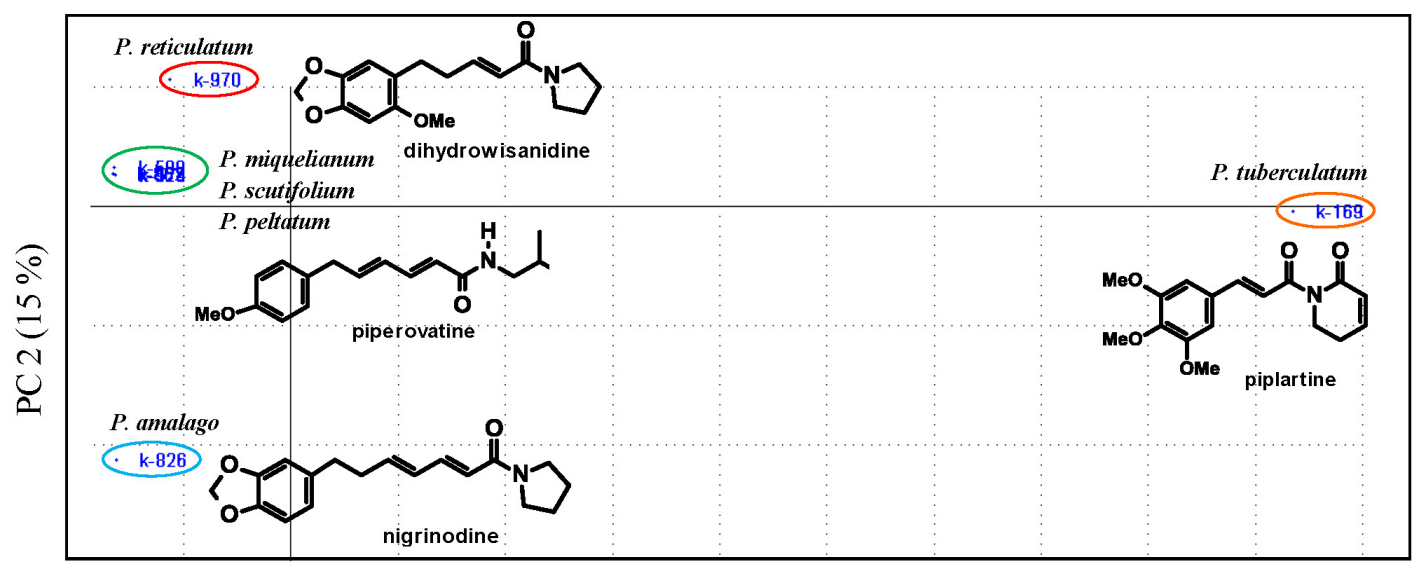

PC $1(68 \%)$

Figure 4. Score plot (PC1 vs. PC2) of ESIMS data of crude extracts from amide-producing Piper species (K-574 and K-923 P. scutifolium, K-870 P. reticulatum, K-169 P. tuberculatum, K-826 P. amalago, K-862 P. miquelianum and K-599 P. peltatum) with 83\% of the variance within the dataset. 
for $P$. reticulatum were not detected in an attempt to dereplicate the extracts from a specimen collected in Carajás City (Pará State, Brazil) using ESIMS data. Nevertheless, the analysis of loading plot of ESIMS data indicated the fragmentary ions at $\mathrm{m} / \mathrm{z} 165$ and 135 instead of those accounted for pyrones in the previous analysis. In order to characterize the compounds responsible for such ions, part of the leaves that were extracted from $P$. reticulatum was fractionated leading to the isolation and characterization of the amides dihydrowisanidine (23a) and wisanidine (23b), the compounds yielding the two fragmentary ions, respectively. In spite of the chemical variability noticed for $P$. reticulatum, such type of comparison should involve more detailed and appropriate samplings, not to mention the genetic variability studies to account for these differences.

\section{Seedling chemistry in Piper species}

In general, the phytochemical investigation has been carried out on adult plants, especially in bioprospecting studies which often require significant amount of material and pure compounds. Comparatively, seedling chemistry is essentially unknown and only few reports were addressed to determine major compounds such as in seedlings of Betula,${ }^{67}$ Virola $^{68}$ Piper $^{69}$ and Pilocarpus ${ }^{70}$ species. Based on such scarcity of data and considering the implication of seedling chemistry in successional ecology and restoration process, four Piper species ( $P$. regnellii, $P$. solmsianum, $P$. gaudichaudianum,
$P$. tuberculatum and $P$. amalago) were examined as compared to adult plants. The seedlings were cultivated under greenhouse and maintained under the same substrate and conditions. Seedling leaves at approximate age of 6 months were analyzed by ESIMS in order to compare with the adult leaves. The score plot of ESIMS data revealed a remarkable difference between leaves from adult plants and seedlings of $P$. solmsianum, $P$. regnellii and $P$. gaudichaudianum (Figure 5). Further analysis using ${ }^{1} \mathrm{H}$ NMR and HPLC characterized the phenylpropanoids dillapiole (4a) and apiole (4b) as major constituents. This profile is quite contrasting with the adult organs of respective species, which consistently contain the lignan grandisin (4), ${ }^{36}$ neolignan conocarpan and derivatives $(\mathbf{6}, \mathbf{7})^{53}$ and chromenes $(\mathbf{1 1 a - 1 1 b}),{ }^{49}$ respectively. The phenylpropanoids dillapiole and apiole are the major constituents in essential oil from leaves of P. aduncum L., ${ }^{71}$ but further compounds also include chromenes ${ }^{37,72}$ and chalcones. ${ }^{73}$ In this specific case, its seedlings also contain dillapiole and apiole as major compounds. On the other hand, the adults and seedling leaves of amidecontaining $P$. tuberculatum and $P$. amalago species were not distinguished between different developmental stages and their composition were based on amides piplartine $(\mathbf{2 0 a})^{48}$ and nigrinodine (28), ${ }^{61}$ respectively. The ESIMS analysis of seedling extracts of $P$. reticulatum indicated differences among leaves from samples collected at Carajás City, cultivated at Instituto de Química (Universidade de São Paulo (USP), São Paulo City) and also from P. amalago.

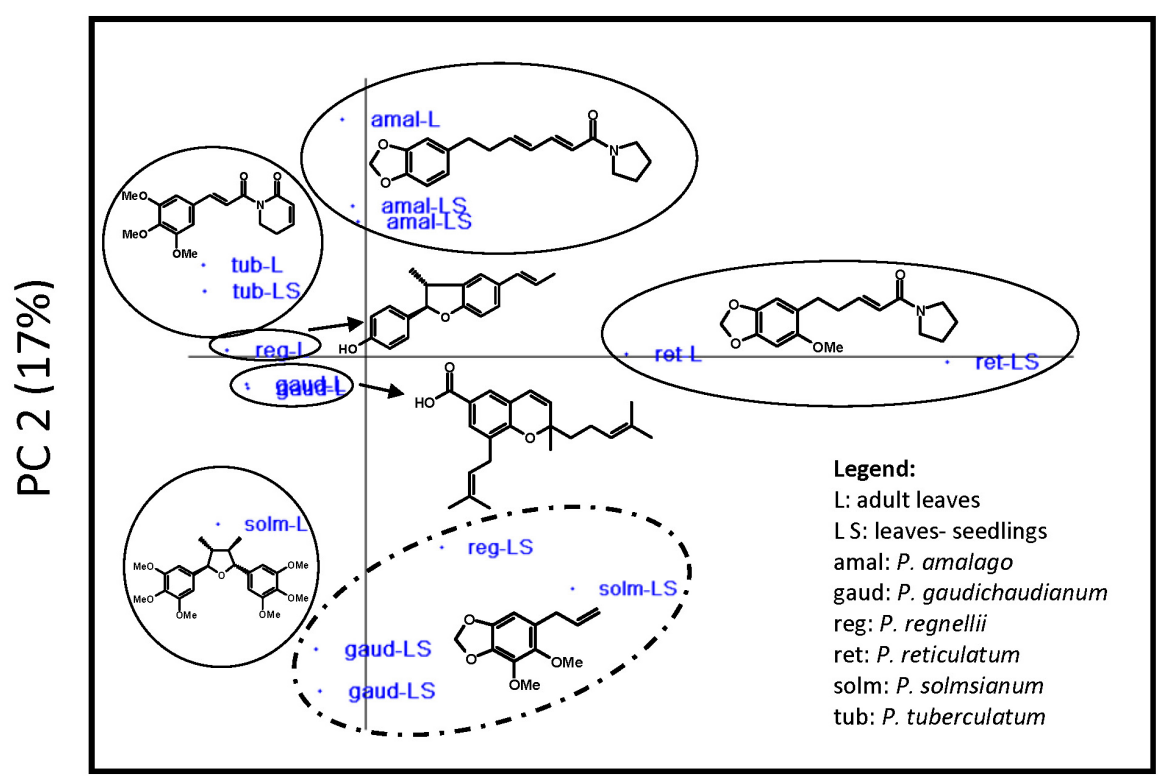

PC $1(48 \%)$

Figure 5. Score plot (PC1 vs. PC2) of ESIMS data of crude extracts of adult and seedlings from Piper species with 65\% of variance within the dataset. Dashed line: dillapiol (plus apiole) in seedling leaves of P. regnellii, P. solmsianum and P. gaudichaudianum. 
Although the seedlings of $P$. reticulatum contained the amides wisanidine (23b) and dihydrowisanidine (23a). Thus, this compound was isolated and fully characterized by the interpretation of 2D NMR as the benzonitrile benzoate (29). This cyanohydrin was previously isolated from Malania oleifera Chun \& Lee (Olacaceae) ${ }^{74}$ and was also described as constituent of defensive secretions of various millipedes species, ${ }^{75}$ but as far as we known this is the first report for Piperaceae species.

\section{Conclusions}

The non-targeted profiling of secondary metabolites for Piper species was carried out in order to determine the major classes of compounds by means of ${ }^{1} \mathrm{H}$ NMR and ESIMS data of crude extracts. The PCA score plot based on ${ }^{1} \mathrm{H}$ NMR or ESIMS data showed a distinction of some lignoid-containing species including the varieties of $P$. solmsianum, $P$. truncatum and $P$. regnellii and also a chromene-containing $P$. hispidum species. The sequential removal of these outlier species still allowed some differentiation in some extent using ${ }^{1} \mathrm{H}$ NMR data but was not enough to provide visible clustering or to clarify chemical similarities among the samples. Nevertheless, the methodology was proven to be valuable when applied to analyze selected set of plant species with specific morphological characteristics such as those having pendant inflorescences (P. caldense, P. carniconnectivum, $P$. bowiei and $P$. permucronatum) belonging to the clade Peltrobryon or to individuals, varieties, organs or different developmental stages as in case of seedlings. Analysis of set of samples by HPLC-UV was also proven to be useful but when combined with ESIMS provides robustness for identification of compounds overcoming the reproducibility limitations based solely on retention time.

The overall analysis of a collection of plant species has only been possible due to the capacity of handling a large number of samples and the corresponding data set generated. Nevertheless, even with the use of high resolution mass spectrometers or high field NMR techniques, the precise determination of structures of secondary compounds in an organism remains one of the major challenges when a complete characterization of the species based on secondary metabolites is concerned.

\section{Experimental}

\section{Plant material}

Piper species (Table 1) were collected in different sites between 2005-2010. The sampling of plant species was carried out under the permit from Instituto Florestal (SMA No. 40.272/2006), Sisbio/MMA (No. 15780-1) and Instituto Brasileiro do Meio Ambiente e dos Recursos Naturais Renováveis (IBAMA, 06/08). The botanical classification was carried out by Dra. Elsie Franklin Guimarães (Instituto de Pesquisas Jardim Botânico do Rio de Janeiro, Brazil) and the vouchers were deposited in this Herbarium (Table 1).

\section{Extract preparations for PCA analysis}

For the PCA analysis, dried and powdered leaves $(2.0 \mathrm{~g})$ of the species were successively extracted with $\mathrm{MeOH}(2 \times 10 \mathrm{~mL})$ at room temperature. The extracts were filtered and concentrated in vacuum to afford the crude $\mathrm{MeOH}$ extracts.

\section{ESIMS analysis for PCA analysis}

The ESIMS analyses were performed in a Quattro II triple quadrupole equipment (Micromass, Manchester, UK). The samples were prepared using the crude extract dissolved in $\mathrm{MeOH}$ in a concentration of $1 \mathrm{mg} \mathrm{mL}^{-1}$. The electrospray positive ionization mode was employed with capillary voltage of $4.5 \mathrm{kV}$, skimmer $50 \mathrm{~V}$ and the nitrogen gas flows of 250 and $30 \mathrm{~L} \mathrm{~h}^{-1}$. Samples were directly injected to MS using mobile phase flow of $50 \mathrm{~mL} \mathrm{~min}^{-1}$ (MeOH: $\mathrm{H}_{2} \mathrm{O} / 1: 1$ ), data were processed by MassLynx (Micromass) version 3.2 (1998).

\section{${ }^{1} H$ NMR analysis for PCA analysis}

Samples for NMR analysis were prepared using $20 \mathrm{mg}$ of $\mathrm{MeOH}$ extract, dissolved in $800 \mu \mathrm{L}$ of $\mathrm{CDCl}_{3}(99.8 \%$ Cambridge Isotopes Laboratories ${ }^{\mathrm{TM}}$ ) containing $0.05 \%$ of TMS (tetramethylsilane). The ${ }^{1} \mathrm{H}$ NMR spectra were performed on a Bruker DPX $300 \mathrm{MHz}$ operating at a proton NMR frequency $300.13 \mathrm{MHz}$ and a $5 \mathrm{~mm}$ probe. Each spectrum consisted of 256 scans and $300 \mathrm{k}$ data point, with a pulse width of $8.0 \mu$ s $\left(30^{\circ}\right)$ and relaxation delay of $2.0 \mathrm{~s}$.

\section{Data analysis}

The spectra were automatically Fourier transformed with a line broadening of $0.3 \mathrm{~Hz}$ by the program MestReC (version 4.8.6.0, MestreLab, 1996), and referenced to residual hydrogen signal $\mathrm{CDCl}_{3}$ at $7.26 \mathrm{ppm}$ using TMS as an internal standard. Spectra signals were integrated in regions of equal width $(0.04 \mathrm{ppm})$ corresponding to the region $\delta 3.00-9.00$. The integrals were obtained for each of the 221 regions and regions containing TMS ( 0 to $0.4 \mathrm{ppm}$ ), 
residues of chloroform (7.0 to $7.4 \mathrm{ppm}$ ) were excluded from each spectrum.

\section{Seedlings}

Seeds of $P$. regnellii, P. solmsianum, $P$. gaudichaudianum and $P$. tuberculatum were collected in the greenhouse of Instituto de Química (USP) and germinated at $27 \pm 2{ }^{\circ} \mathrm{C}$ under $16 \mathrm{~h}$ photoperiod $\left(35 \mathrm{mmol} \mathrm{m}^{-2} \mathrm{~s}^{-1}, 85 \mathrm{~W}\right.$ cool-white fluorescent lamps). Seedlings of approximately 6 months age had their leaves extracted and analyzed by ESIMS.

\section{Analysis by PCA}

The ${ }^{1} \mathrm{H}$ NMR and ESIMS data were exported in ASCII format to Microsoft Excel to produce a data matrix of sample versus metabolite peak/mass with associated peak/mass areas, prior to further principal component analysis using the Unscrambler software version 9.5 (CAMO Process AS, Norway, 1996-2007). The normalization process of the raw data, which consisted of making the area under each curve the same for all spectra, was carried out to avoid possible lack of reproducibility associated to dilution effects and responses of the mass detector.

\section{Isolation general experimental procedures}

Silica gel (Merck 230-400 mesh) and reversed phase silica $\mathrm{C}_{18}$ (Waters, $125 \AA$, 55-105 mm) were used for column chromatographic separation while silica gel 60 PF254 (Merck) was used for analytical $(0.25 \mathrm{~mm})$ and prep-thin layer chromatograph (TLC) $(1.0 \mathrm{~mm})$. Analytical HPLC was performed using a Shimadzu chromatograph model SCL-10A with UV-Vis detector (model SPD-M10A) and $\mathrm{C}_{18}$ column $(250 \mathrm{~mm} \times 5 \mathrm{~mm}, 5 \mathrm{~mm})$, methanol (B) and water (A) were used as mobile phase. Samples of extracts were dissolved in $\mathrm{MeOH}: \mathrm{H}_{2} \mathrm{O}(90 \%)$ at a concentration of $1 \mathrm{mg} \mathrm{mL}^{-1}$, cleaned up through Sep-pack $\mathrm{C}_{18}$ and submitted to HPLC-PDA-ESIMS analysis.

${ }^{1} \mathrm{H}$ NMR spectra were recorded at 300 and $500 \mathrm{MHz}$ and ${ }^{13} \mathrm{C}$ NMR at 75 and $125 \mathrm{MHz}$ in Bruker DPX-300 and DPX-500 spectrometers. $\mathrm{CDCl}_{3}$ and $\mathrm{CD}_{3} \mathrm{OD}$ (Cambridge Isotope) containing $0.05 \%$ of TMS as internal standard were applied. Chemical shifts are reported in $\delta$ units (ppm) and coupling constants $(J)$ in Hz. HREIMS were obtained on a Bruker Daltonics MicroTOF mass spectrometer. LREIMS (low resolution electron impact-mass spectrometry) data were acquired in a HP 5990/5988A mass spectrometer, and GCLREIMS (gas chromatography electron impact-mass spectrometry) data were acquired in a Shimadzu GC-17A chromatograph interfaced with a MS-QP-5050A mass spectrometer.

\section{Extraction and isolation of constituents from P. richardiaefolium}

Dried leaves $(68.0 \mathrm{~g})$ were extracted three times for $24 \mathrm{~h}$ with EtOAc yielding $8.0 \mathrm{~g}$ of crude extract. The extract of leaves was dissolved in $\mathrm{MeOH}: \mathrm{H}_{2} \mathrm{O}$ (20\%), filtrated on a Celite bed and the filtered solution extracted with dichloromethane. The organic fraction was dried with anhydrous sodium sulfate and then, the solvents were evaporated under vacuum to yield $2.5 \mathrm{~g}$. This fraction was subjected to a vacuum liquid chromatography (VLC) using silica gel eluted with a gradient of hexane and EtOAc resulting in 19 fractions. Fraction 5 was subjected to prepTLC eluted with hexane:EtOAc (20\%) yielding sesamin $(\mathbf{8 b})^{76}$ and hinokinin $(\mathbf{9 a}) .^{77}$ Fractions 9-12 yielded kobusin $(\mathbf{8 c}, 23 \mathrm{mg}),{ }^{54}$ kusunokinin $(\mathbf{9 b}, 11 \mathrm{mg})^{77}$ and cubebin (10a, $85 \mathrm{mg}){ }^{68}$ Fractions $15-19$ were submitted to prep-TLC yielding 3',4'-dimethoxy-3,4-demethylenedioxycubebin $(\mathbf{1 0 b}, 6 \mathrm{mg})^{76}$ and arctigenin $(\mathbf{9 c}, 18 \mathrm{mg}){ }^{78}$

\section{Extraction and isolation of constituents from P. reticulatum}

Dried and powdered leaves of $P$. reticulatum (100 g) were extracted with EtOAc two times, during two days, at room temperature. Part of the extract ( $3 \mathrm{~g}$ ) was subjected to flash silica gel column chromatography eluted with $n$-hexane containing increasing amounts of EtOAc (up to $100 \%)$, to give 11 fractions. Fraction $5(126 \mathrm{mg}$ ) was purified by silica gel preparative TLC (hexane-EtOAc, 7:3, two elutions) affording cyanobenzyl benzoate (29, $8 \mathrm{mg})$. Fraction $11(250 \mathrm{mg})$ was fractionated by VLC reversed phase eluted with water and increasing amounts of $\mathrm{MeOH}$ (up to 100\%), yielding 9 fractions. Fraction 1 (33 mg) was purified by silica gel preparative TLC $\left(\mathrm{CH}_{2} \mathrm{Cl}_{2}-\mathrm{MeOH}\right.$, 9.5:0.5, two elutions) affording dihydrowisanidine (23a), ${ }^{79}$ which was the major compound.

\section{Extraction and isolation of constituents from P. bowiei and P. permucronatum}

Dried and powdered leaves of $P$. bowiei $(12 \mathrm{~g})$ and P. permucronatum $(10 \mathrm{~g})$ were extracted with EtOAc $(2 \times 500 \mathrm{~mL})$ at room temperature. The extracts were filtered and concentrated in vacuum to afford the crude extracts. The P. bowiei extract ( $1.65 \mathrm{~g})$ was subjected to VLC on silica gel eluted with gradient mixtures of $n$-hexane/EtOAc and EtOAc/MeOH to afford 14 fractions. The fraction 5 (400 mg) was subjected to separation on 
Sephadex LH-20 column chromatography eluted with $\mathrm{MeOH}$ to afford a pure flavanone (18), identified as dihydrowogonin (5,7-dihydroxy-8-methoxyflavanone), the EIMS, ${ }^{1} \mathrm{H}$ and ${ }^{13} \mathrm{C}$ NMR data were identical to that described. ${ }^{70}$

The $P$. permucronatum extract $(1.62 \mathrm{~g})$ was subjected to VLC on silica gel eluted with gradient mixtures of $n$-hexane/EtOAc and EtOAc/MeOH to afford 16 fractions. The fraction $9(230 \mathrm{mg})$ was subjected to separation on Sephadex LH-20 column chromatography eluted with $\mathrm{MeOH}$ to afford a pure flavanone, identified as sakuranetin (17a) (5,4'-dihydroxy-7-methoxyflavanone), the EIMS, ${ }^{1} \mathrm{H}$ and ${ }^{13} \mathrm{C}$ NMR data were identical to that described. ${ }^{70}$

\section{Acknowledgments}

The authors acknowledge IBAMA and Vale do Rio Doce for permission to collect plant material at Floresta Nacional (FLONA) de Carajás and to Prof. Paolo Di Mascio for ESIMS facility and to Conselho Nacional de Desenvolvimento Científico e Tecnológico (CNPq), Coordenação de Aperfeiçoamento de Pessoal de Nível Superior (CAPES) and Fundação de Amparo à Pesquisa do Estado de São Paulo (FAPESP) for providing research funding.

\section{References}

1. Fiehn, O.; Plant Mol. Biol. 2002, 48, 155.

2. Rochfort, S.; J. Nat. Prod. 2005, 68, 1813.

3. Shulaev, V.; Cortes, D.; Miller, G.; Mittler, R.; Plant Physiol. 2008, 132, 199.

4. Wishart, D. S.; Drugs R\&D 2008, 9, 307.

5. Moco, S.; Schneider, B.; Vervoort, J.; J. Proteome Res. 2009, $8,1694$.

6. t'Kindt, R.; Morreel, K.; Deforce, D.; Boerjan, W.; Van Bocxlaer, J.; J. Chromatogr., B: Anal. Technol. Biomed. Life Sci. 2009, 877, 3572.

7. Ohashi, Y.; Hirayama, A.; Ishikawa, T.; Nakamura, S.; Shimizu, K.; Ueno, Y.; Tomita, M.; Soga, T.; Mol. BioSyst. 2008, 4, 135.

8. Hagel, J. M.; Weljie, A. M.; Vogel, H. J.; Facchini, P. J.; Plant Physiol. 2008, 147, 1805.

9. Rochfort, S. J.; Trenerry, V. C.; Imsic, M.; Panozzo, J.; Jones, R.; Phytochemistry 2008, 69, 1671.

10. Monton, M. R. N.; Soga, T.; J. Chromatogr., A 2007, 1168, 237.

11. Zhao, J.; Avula, B.; Joshi, V. C.; Techen, N.; Wang, Y.-H.; Smillie, T. J.; Khan, I. A.; Planta Med. 2011, 77, 851.

12. Safer, S.; Cicek, S. S.; Pieri, V.; Schwaiger, S.; Schneider, P.; Wissemann, V.; Stuppner, H., Phytochemistry 2011, 72, 1379.

13. Yi, L. E.; Yuan, D. L.; Liang, Y. Z.; Xie, P. S.; Zhao, Y.; Anal. Chim. Acta 2009, 649, 43.
14. Kim, H. K.; Choi, Y. H.; Verpoorte, R.; Nat. Protoc. 2010, 5, 536.

15. Lowe, R. G. T.; Allwood, J. W.; Galster, A. M.; Urban, M.; Daudi, A.; Canning, G.; Ward, J. L.; Beale, M. H.; Hammond-Kosack, K. E.; Mol. Plant-Microbe Interact. 2010, 23, 1605.

16. Figueiredo, R. A.; Sazima, M.; Plant Biology 2007, 9, 136.

17. Ramos, C.; Vanin, S.; Kato, M.; Chemoecology 2009, 19, 73.

18. Ramos, C. S.; Vanin, S. A.; Kato, M. J.; Phytochemistry 2008 , 69, 2157.

19. Vanin, S. A.; Ramos, C. S.; Guimaraes, E. F.; Kato, M. J.; Rev. Bras. Entomol. 2008, 52, 72.

20. Dyer, L. A.; Letourneau, D. K.; Dodson, C. D.; Tobler, M. A.; Stireman, J. O.; Hsu, A.; Ecology 2004, 85, 2795.

21. Kitamura, R. O. S.; Romoff, P.; Young, M. C. M.; Kato, M. J.; Lago, J. H. G.; Phytochemistry 2006, 67, 2398.

22. Marques, J. V.; de Oliveira, A.; Raggi, L.; Young, M. C. M.; Kato, M. J.; J. Braz. Chem. Soc. 2010, 21, 1807.

23. Kato, M. J.; Furlan, M.; Pure Appl. Chem. 2007, 79, 529.

24. Batista, J. M.; Lopes, A. A.; Ambrosio, D. L.; Regasini, L. O.; Kato, M. J.; Bolzani, V. S.; Cicarelli, R. M. B.; Furlan, M.; Biol. Pharm. Bull. 2008, 31, 538.

25. Parmar, V. S.; Jain, S. C.; Bisht, K. S.; Jain, R.; Taneja, P.; Jha, A.; Tyagi, O. D.; Prasad, A. K.; Wengel, J.; Olsen, C. E.; Boll, P. M.; Phytochemistry 1997, 46, 597.

26. Scott, I. M.; Jensen, H. R.; Philogène, B. J. R.; Arnason, J. T.; Phytochem. Rev. 2008, 7, 65.

27. Batista, J. M.; Batista, A. N. L.; Rinaldo, D.; Vilegas, W.; Cass, Q. B.; Bolzani, V. S.; Kato, M. J.; Lopez, S. N.; Furlan, M.; Nafie, L. A.; Tetrahedron: Asymmetry 2010, 21, 2402.

28. Morandim-Giannetti, A. D.; Pin, A. R.; Pietro, N. A. S.; de Oliveira, H. C.; Mendes-Giannini, M. J. S.; Alecio, A. C.; Kato, M. J.; de Oliveira, J. E.; Furlan, M.; J. Med. Plants Res. 2010, 4, 1810.

29. de Lira, P. N. B.; da Silva, J. K. R.; Andrade, E. H. A.; Sousa, P. J. C.; Silva, N. N. S.; Maia, J. G. S.; Nat. Prod. Commun. 2009, 4, 427.

30. de Lira, P. N. B.; da Silva, J. K. R.; Andrade, E. H. A.; Sousa, P. J. C.; Silva, N. N. S.; Maia, J. G. S.; Nat. Prod. Commun. 2009, 4, 427.

31. dos Santos, P. R. D.; Moreira, D. L.; Guimaraes, E. F.; Kaplan, M. A. C.; Phytochemistry 2001, 58, 547.

32. Lago, J. H. G.; de Oliveira, A.; Guimaraes, E. F.; Kato, M. J.; J. Braz. Chem. Soc. 2007, 18, 638.

33. Estrela, J. L. V.; Fazolin, M.; Catani, V.; Alecio, M. R.; de Lima, M. S.; Pesq. Agropec. Bras. 2006, 41, 217.

34. Achenbach, H.; Fietz, W.; Worth, J.; Waibel, R.; Portecop, J.; Planta Med. 1986, 1, 12.

35. Scott, I. M.; Puniani, E.; Jensen, H.; Livesey, J. F.; Poveda, L.; Sanchez-Vindas, P.; Durst, T.; Arnason, J. T.; J. Agric. Food Chem. 2005, 53, 1907.

36. Martins, R. C. C.; Latorre, L. R.; Sartorelli, P.; Kato, M. J.; Phytochemistry 2000, 55, 843. 
37. Baldoqui, D. C.; Kato, M. J.; Cavalheiro, A. J.; Bolzani, V. S.; Young, M. C. M.; Furlan, M.; Phytochemistry 1999, 51, 899.

38. Orjala, J.; Erdelmeier, C. A. J.; Wright, A. D.; Rali, T.; Sticher, O.; Phytochemistry 1993, 34, 813.

39. Jacobs, H.; Seeram, N. P.; Nair, M. G.; Reynolds, W. F.; McLean, S.; J. Indian Chem. Soc. 1999, 76, 713.

40. Silva, R. V.; Navickiene, H. M. D.; Kato, M. J.; Bolzani, V. S.; Meda, C. I.; Young, M. C. M.; Furlan, M.; Phytochemistry 2002, 59, 521.

41. Freitas, G. C.; Kitamura, R. O. S.; Lago, J. H. G.; Young, M. C. M.; Guimarães, E. F.; Kato, M. J.; Phytochem. Lett. 2009, 2, 119.

42. Danelutte, A. P.; Costantin, M. B.; Delgado, G. E.; Braz-Filho, R.; Kato, M. J.; J. Braz. Chem. Soc. 2005, 16, 1425.

43. Marques, J. V.; Kitamura, R. O. S.; Lago, J. H. G.; Young, M. C.M.; Guimaraes, E.F.; Kato, M. J.; J.Nat.Prod. 2007, 70, 2036.

44. Yamaguchi, L. F.; Lago, J. H. G.; Tanizaki, T. M.; Di Mascio, P.; Kato, M. J.; Phytochemistry 2006, 67, 1838.

45. Danelutte, A. P.; Lago, J. H. G.; Young, M. C. M.; Kato, M. J.; Phytochemistry 2003, 64, 555.

46. Terreaux, C.; Gupta, M. P.; Hostettmann, K.; Phytochemistry 1998, 49, 461.

47. Lopes, A. A.; Baldoqui, D. C.; Lopez, S. N.; Kato, M. J.; Bolzani, V. S.; Furlan, M.; Phytochemistry 2007, 68, 2053.

48. Navickiene, H. M. D.; Alecio, A. C.; Kato, M. J.; Bolzani, V. S.; Young, M. C. M.; Cavalheiro, A. J.; Furlan, M.; Phytochemistry 2000, 55, 621 .

49. Lago, J. H. G.; Ramos, C. S.; Casanova, D. C. C.; Morandim, A. D.; Bergamo, D. C. B.; Cavalheiro, A. J.; Bolzani, V. S.; Furlan, M.; Guimaraes, E. F.; Young, M. C. M.; Kato, M. J.; J. Nat. Prod. 2004, 67, 1783.

50. Lago, J. H. G.; Young, M. C. M.; Reigada, J. B.; Soares, M. G.; Roesler, B. P.; Kato, M. J.; Quim. Nova 2007, 30, 1222.

51. de Oliveira, A.; Silva, C. A.; Silva, A. M.; Tavares, M. F. M.; Kato, M. J.; Phytochem. Anal. 2010, 21, 428.

52. Raimundo, J. M.; Trindade, A. P. F.; Velozo, L. S. M.; Kaplan, M. A. C.; Sudo, R. T.; Zapata-Sudo, G.; Eur. J. Pharmacol. 2009, 606, 150.

53. Benevides, P. J. C.; Sartorelli, P.; Kato, M. J.; Phytochemistry 1999, 52, 339.

54. Leong, Y.-W.; Harrison, L. J.; Powell, A. D.; Phytochemistry 1999, 50, 1237.

55. Maxwell, A.; Dabideen, D.; Reynolds, W. F.; McLean, S.; J. Nat. Prod. 1998, 61, 815.

56. Vinciguerra, V.; Luna, M.; Bistoni, A.; Zollo, F.; Phytochem. Anal. 2003, 14, 371.

57. Jaramillo, M. A.; Callejas, R.; Davidson, C.; Smith, J. F.; Stevens, A. C.; Tepe, E. J.; Syst. Bot. 2008, 33, 647.

58. Junior, E. L. C.; Chaves, M. C. D.; Pharm. Biol. 2003, 41, 216.

59. Facundo, V. A.; Rezende, C. M.; Pinto, A. C.; J. Essent. Oil Res. 2006, 18, 296.
60. Facundo, V. A.; Braz-Filho, R.; Biochem. Syst. Ecol. 2004, 32 , 1215.

61. Alves, H. S.; de Oliveira, G. E.; Zoghbi, M. G.; Chaves, M. C. O.; Braz. J. Pharmacog. 2010, 20, 160.

62. de Morales, S. M.; Facundo, V. A.; Bertini, L. M.; Cavalcanti, E. S. B.; dos Anjos, J. F.; Ferreira, S. A.; de Brito, E. S.; de Souza Neto, M. A.; Biochem. Syst. Ecol. 2007, 35, 670.

63. Jaramillo, M. A.; Manos, P. S.; Am. J. Bot. 2001, 88, 706.

64. Setzer, W. N.; Park, G.; Agius, B. R.; Stokes, S. L.; Walker, T. M.; Haber, W. A.; Nat. Prod. Commun. 2008, 3, 1367.

65. Achenbach, H.; Gross, J.; Portecop, J.; Planta Med. 1984, 50, 528.

66. Carrara, V. D.; de Souza, A.; Dias, B. P.; Nakamura, C. V.; de Paulo, L. F.; Young, M. C. M.; Svidzinski, T. I. E.; Cortez, D. A. G.; Lat. Am. J. Pharm. 2010, 29, 1459.

67. Tiainen, M.; Pusenius, J.; Julkunen-Tiitto, R.; Roininen, H.; J. Chem. Ecol. 2006, 32, 2287.

68. Kato, M. J.; Yoshida, M.; Gottlieb, O. R.; Phytochemistry 1992, $31,283$.

69. Navickiene, H. M. D.; Bolzani, V. S.; Kato, M. J.; Pereira, A. M. S.; Bertoni, B. W.; Franca, S. C.; Furlan, M.; Phytochem. Anal. 2003, 14, 281.

70. Abreu, I. N.; Choi, Y. H.; Sawaya, A. C. H. F.; Eberlin, M. N.; Mazzafera, P.; Verpoorte, R.; Planta Med. 2011, 77, 293.

71. Maia, J. G. S.; Zohhbi, M. D. B.; Andrade, E. H. A.; Santos, A. S.; da Silva, M. H. L.; Luz, A. I. R.; Bastos, C. N.; Flavour Fragrance J. 1998, 13, 269.

72. Moreira, D. D.; Guimaraes, E. F.; Kaplan, M. A. C.; Phytochemistry 1998, 48, 1075.

73. Torres-Santos, E. C.; Moreira, D. L.; Kaplan, M. A. C.; Meirelles, M. N.; Rossi-Bergmann, B.; Antimicrob. Agents Chemother. 1999, 43, 1234.

74. Liu, X. M.; Li, W. G.; Li, P. Y.; Zhou, Y. H.; Yingyong Huaxue 2007, 24, 968.

75. Darling, D. C.; Schroeder, F. C.; Meinwald, J.; Eisner, M.; Eisner, T.; Naturwissenschaften 2001, 88, 306.

76. Vidigal, M. C. S.; Cavalheiro, A. J.; Kato, M. J.; Yoshida, M.; Phytochemistry 1995, 40, 1259.

77. Kato, M. J.; Yoshida, M.; Gottlieb, O. R.; Phytochemistry 1990, 29, 1799.

78. Koulman, A.; Kubbinga, M. E.; Batterman, S.; Woerdenbag, H. J.; Pras, N.; Woolley, J. G.; Quax, W. J.; Planta Med. 2003, 69, 733.

79. Sondengam, B. L.; Kimbu, S. F.; Connolly, J. D.; Phytochemistry 1977, 16, 1121.

Submitted: September 5, 2011

Published online: December 6, 2011

FAPESP has sponsored the publication of this article. 


\title{
Chemometric Analysis of ESIMS and NMR Data from Piper Species
}

\author{
Lydia F. Yamaguchi, ${ }^{a}$ Giovana C. Freitas, ${ }^{a}$ Nidia C. Yoshida, ${ }^{a}$ Renata A. Silva, ${ }^{a}$ Anderson M. Gaia, ${ }^{a}$ \\ Adalberto M. Silva, ${ }^{a}$ Marcus T. Scotti, ${ }^{b}$ Vicente de P. Emerenciano, ${ }^{a}$ Elsie F. Guimarães, ${ }^{c}$ \\ Eny I. S. Floh, ${ }^{d}$ Carlos A. Colombo, ${ }^{e}$ Walter J. Siqueira ${ }^{e}$ and Massuo J. Kato*,a \\ ${ }^{a}$ Departamento de Química Fundamental, Instituto de Química, Universidade de São Paulo, \\ 05508-000 São Paulo-SP, Brazil
}

${ }^{b}$ Centro de Ciências Aplicadas e Educação (Campus IV), Universidade Federal da Paraíba, 58297-000 Rio Tinto-PB, Brazil

'Instituto de Pesquisas Jardim Botânico do Rio de Janeiro, Rua Jardim Botânico, 1008, 22460-070 Rio de Janeiro-RJ, Brazil

${ }^{d}$ Departamento de Botânica, Instituto de Biociências, Rua do Matão, 277, 05422-970 São Paulo-SP, Brazil

${ }^{e}$ Centro de Genética Biologia Molecular e Fitoquímica, Instituto Agronômico de Campinas, Av. Barão de Itapura, 1481, 13001-970 Campinas-SP, Brazil

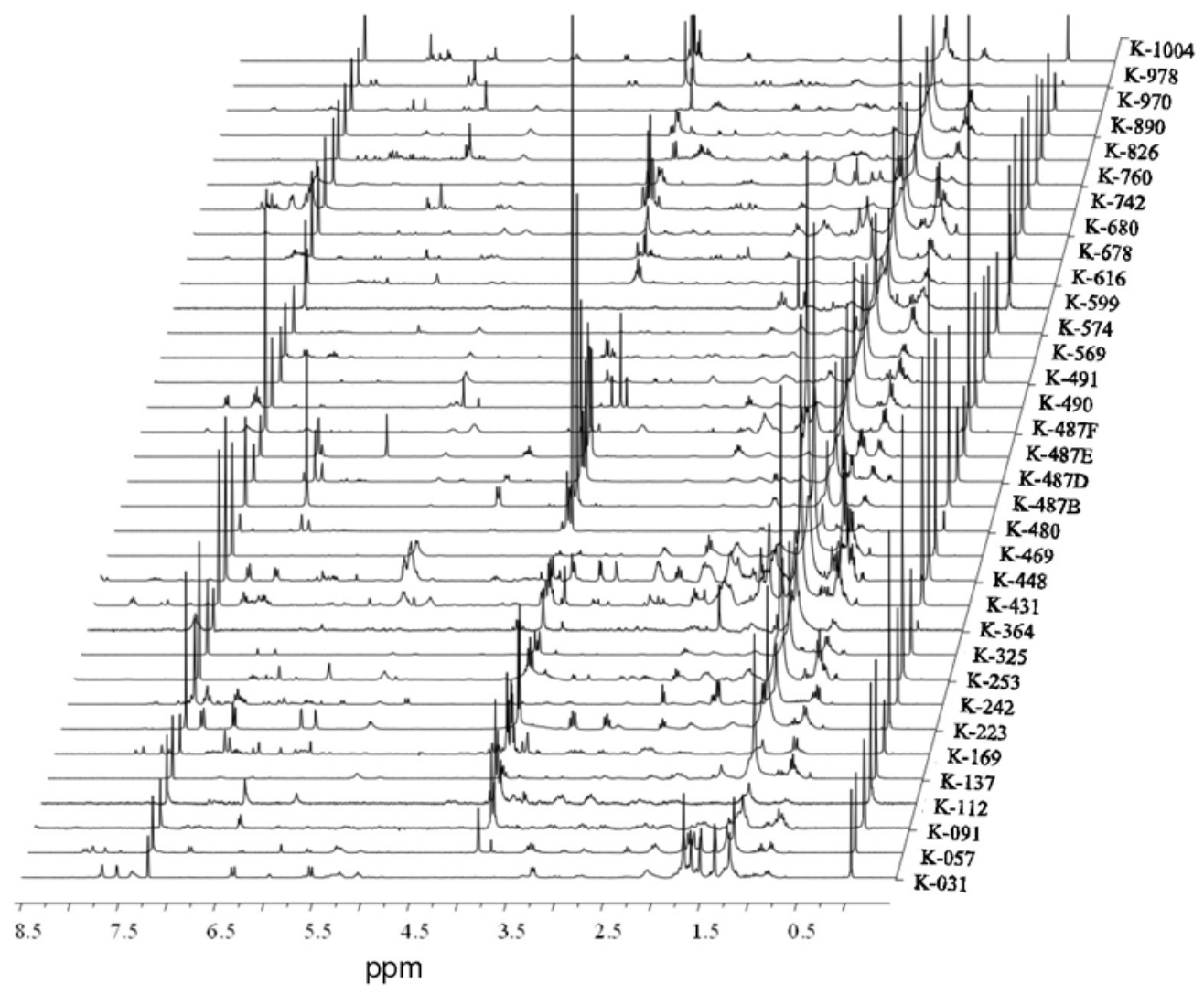

Figure S1. ${ }^{1} \mathrm{H}$ NMR $\left(300 \mathrm{MHz}, \mathrm{CDCl}_{3}\right)$ spectra of crude extracts from Piper species. 
pca

130509 Gi k-963 ta 63 (4. 304)

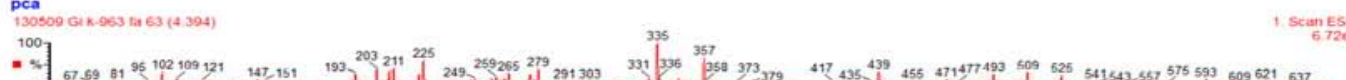
130509 aik-480 ta 60 (4204)

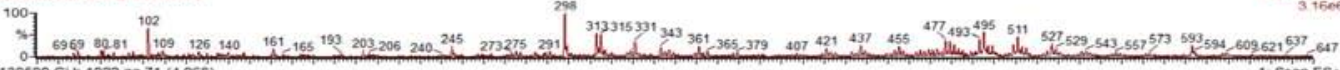
10500 Gik-1022 9371 (4.065) 130

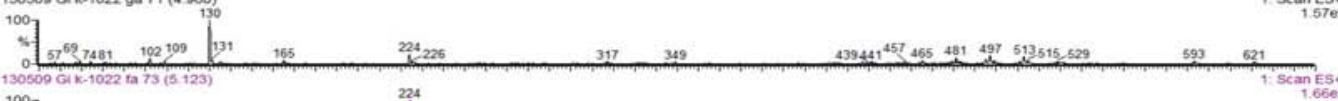

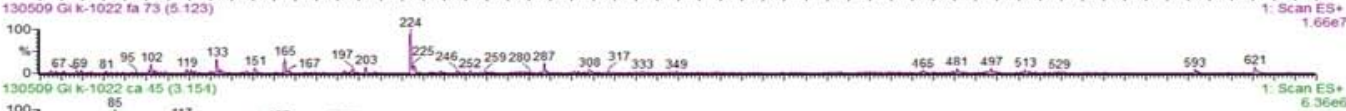

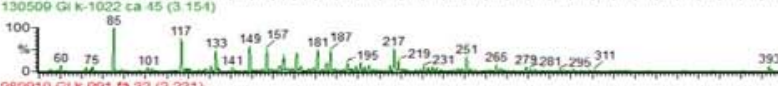

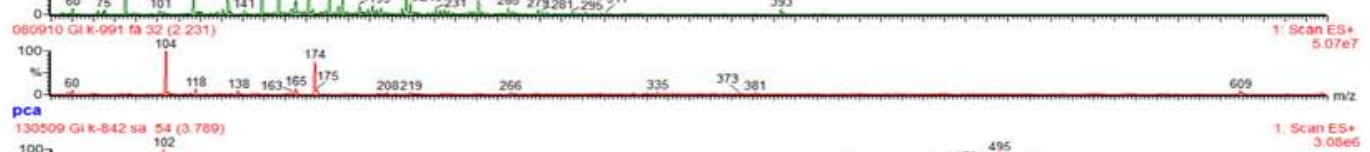

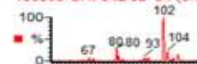

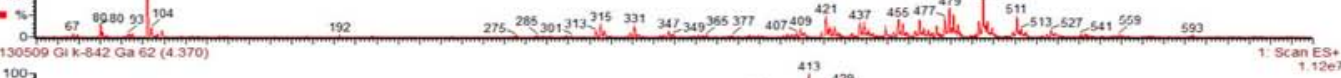

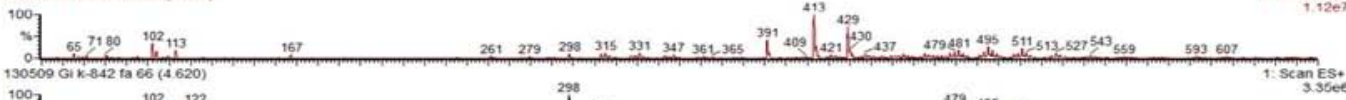

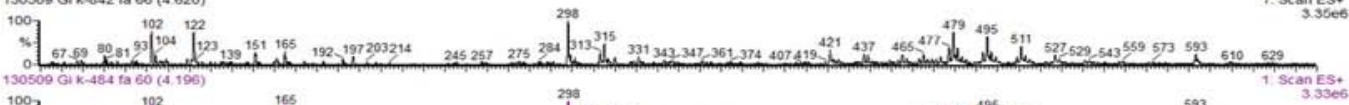

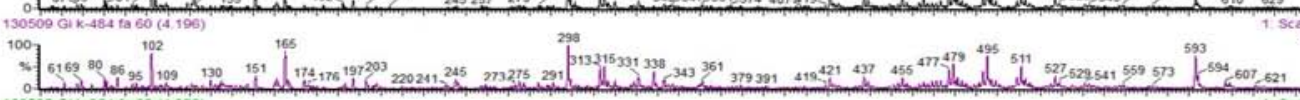

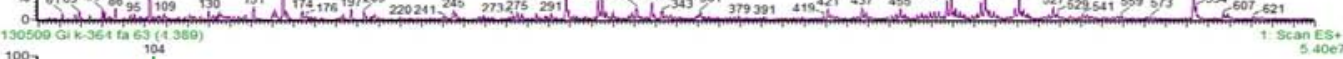

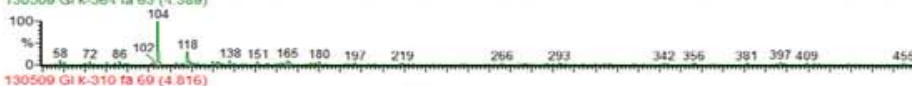

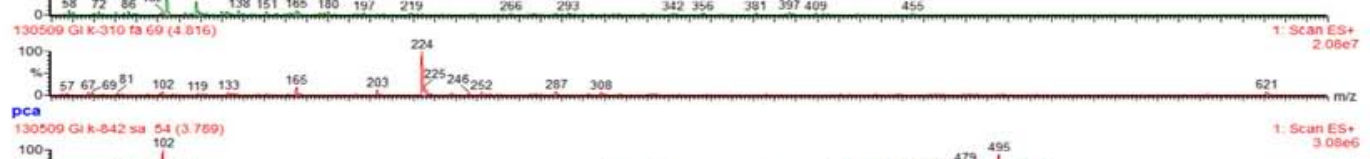

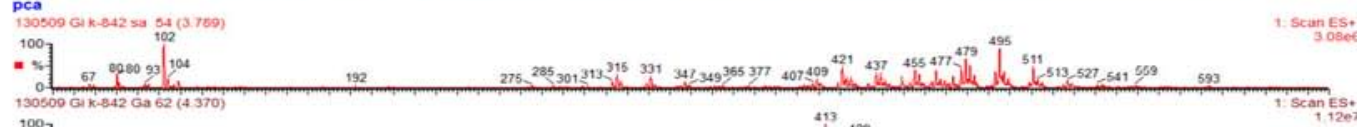

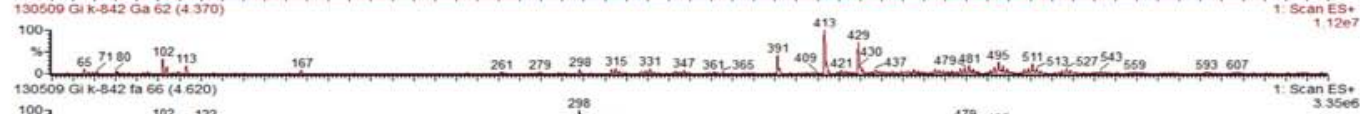

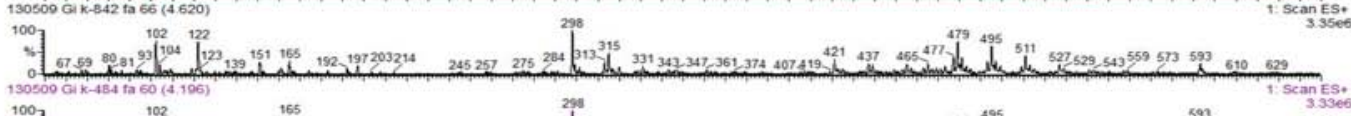

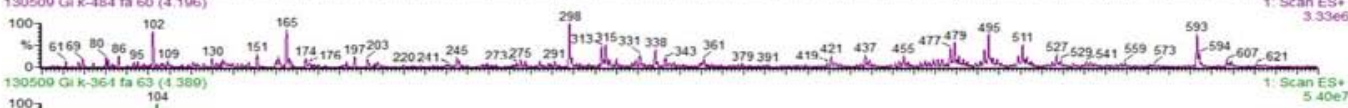

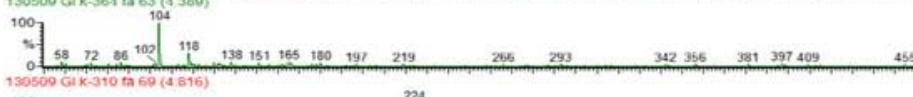

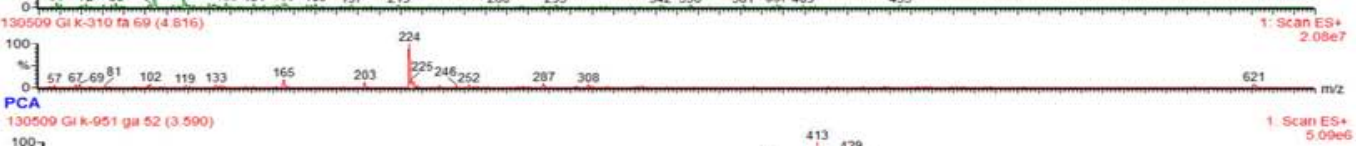

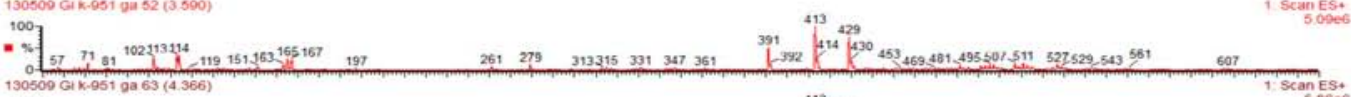
130509 Gik.951 tra 63(4.369)

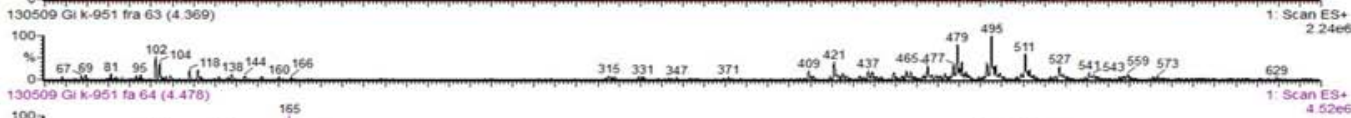

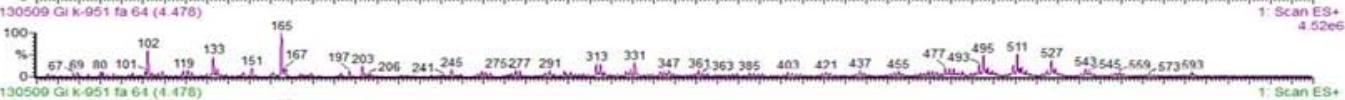

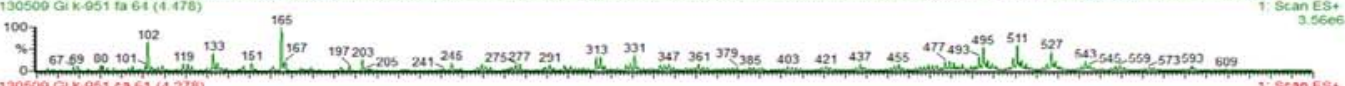

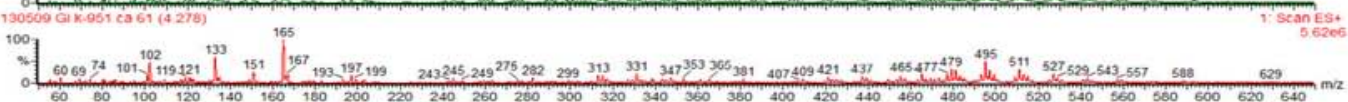

Figure S2. ESIMS data of crude extracts from selected Piper species. 


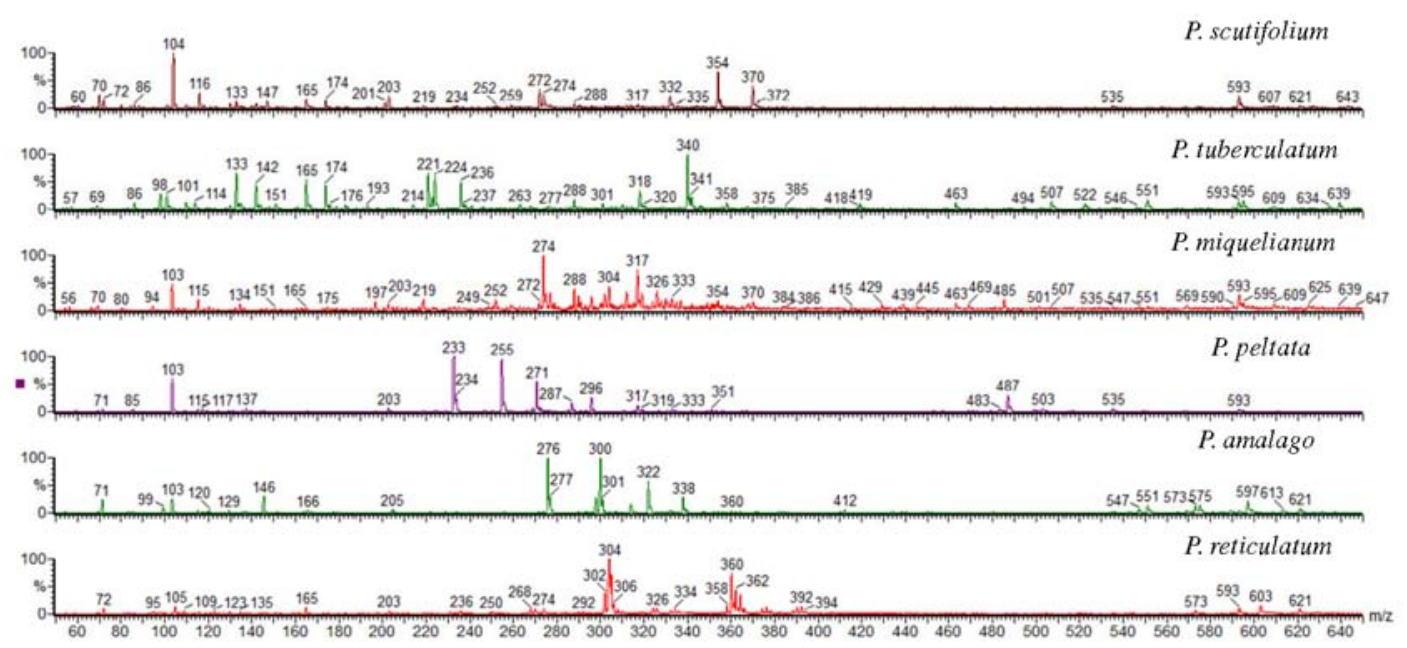

Figure S3. ESIMS spectra of crude extracts from amide-producing Piper species.

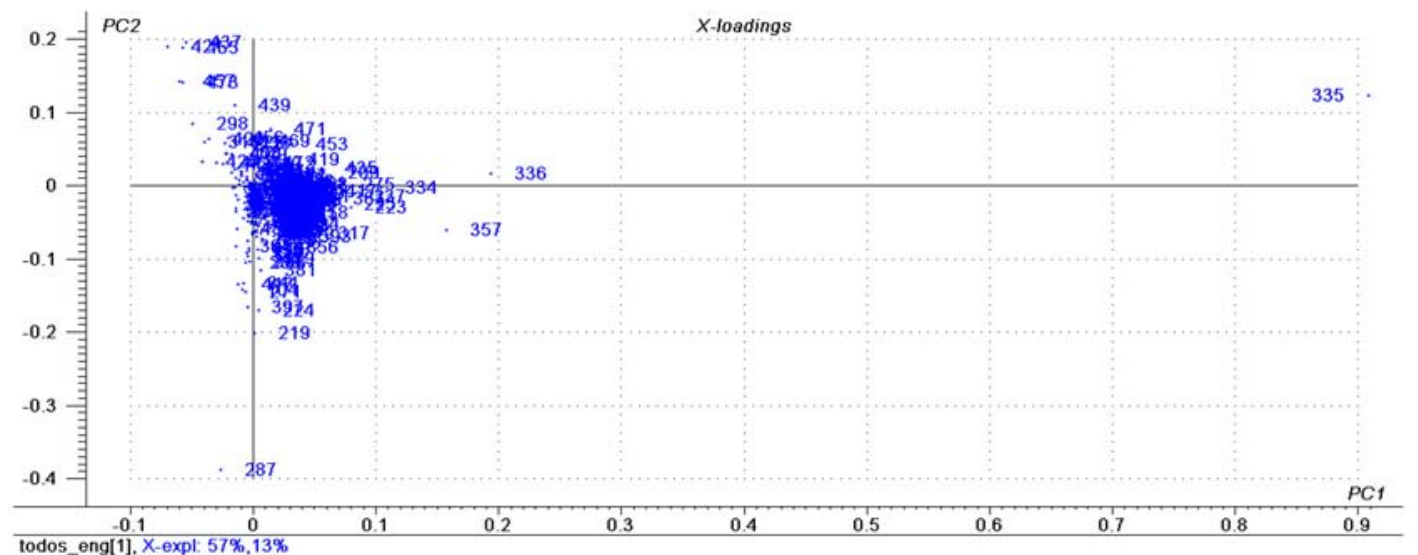

Figure S4. Loading plot of ESIMS of crude extracts from selected Piper species with $70 \%$ of the variance within the data set.

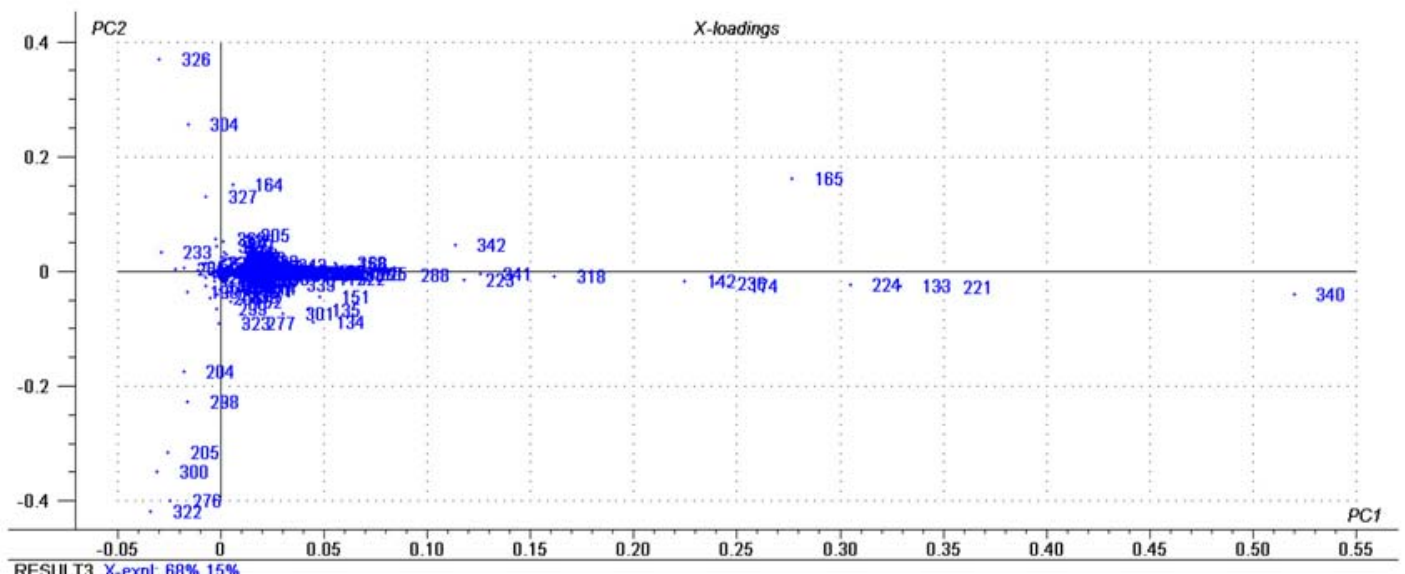

Figure S5. Loading plot of ESIMS of crude extracts from amide-producing Piper species. 